\title{
"Human capital and credit risk management: training is more valuable than experience"
}

Ghassen Bouslama (D https://orcid.org/0000-0003-3059-6952

AUTHORS Christophe Bouteiller iD https://orcid.org/0000-0002-4574-2978

R http://www.researcherid.com/rid/C-6230-2019

Ghassen Bouslama and Christophe Bouteiller (2019). Human capital and credit

ARTICLE INFO risk management: training is more valuable than experience. Problems and Perspectives in Management, 17(1), 67-77. doi:10.21511/ppm.17(1).2019.07

DOI http://dx.doi.org/10.21511/ppm.17(1).2019.07

RELEASED ON Wednesday, 13 February 2019

RECEIVED ON

Friday, 11 January 2019

ACCEPTED ON

Tuesday, 29 January 2019

\section{(c)) EY}

LICENSE

This work is licensed under a Creative Commons Attribution 4.0 International License

JOURNAL Problems and Perspectives in Management"

ISSN PRINT 1727-7051

ISSN ONLINE $1810-5467$

PUBLISHER

LLC "Consulting Publishing Company "Business Perspectives"

FOUNDER

LLC "Consulting Publishing Company "Business Perspectives"

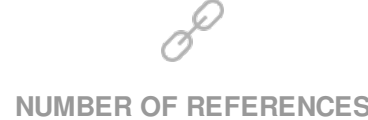

44

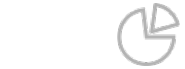

NUMBER OF FIGURES

0
ニニュ

NUMBER OF TABLES

11

(C) The author(s) 2021. This publication is an open access article. 


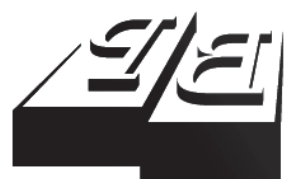

BUSINESS PERSPECTIVES

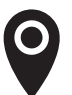

LLC "CPC "Business Perspectives" Hryhorii Skovoroda lane, 10, Sumy, 40022, Ukraine

www.businessperspectives.org

Received on: $11^{\text {th }}$ of January, 2019 Accepted on: $29^{\text {th }}$ of January, 2019

(C) Ghassen Bouslama, Christophe Bouteiller, 2019

Ghassen Bouslama, Ph. D., Associate Professor of Finance, NEOMA Business School, Campus of Reims, France.

Christophe Bouteiller, Ph. D., Professor of Finance, NEOMA Business School, Campus of Reims, France.

\section{(ㄷ)(i)}

This is an Open Access article, distributed under the terms of the Creative Commons Attribution 4.0 International license, which permits unrestricted re-use, distribution, and reproduction in any medium, provided the original work is properly cited.

\section{HUMAN CAPITAL}

AND CREDIT RISK MANAGEMENT: TRAINING IS MORE VALUABLE THAN EXPERIENCE

\begin{abstract}
The aim of this article is to assess how human capital, and more specifically training and experience, helps in forecasting and monitoring credit risk. It uses a survey of a sample of loan officers in a major French mutualist bank and applies analysis of variance and correlation to determine the relationships among variables. The study of these two components of human capital in SME loan officers shows that their ability to anticipate risk depends above all on their training rather than on their experience. Some methods of anticipating risk are more important than others. Loan officers monitor their clients in similar ways, whatever the degree and nature of their experience. The findings have two important implications for credit risk management and human capital: first, both technical and regulatory training is crucial to enable loan officers to anticipate bank credit risk, second, experience, whether in banking or as a loan officer, only makes a difference in monitoring risk. These results will be useful when banks are planning recruitment, career management and resource and skills allocation. They also suggest that staff knowledge management will enable banks to use their human capital effectively to reach their own objectives with regard to risk control, and those fixed by the regulators. This work is, as far as it is known, the first to study the role of human capital in managing credit risk. The authors show that training is more important than experience in default risk anticipation, but that experience is useful in risk monitoring.
\end{abstract}

\section{Keywords}

credit risk, training in banking, banking experience, risk anticipation, risk monitoring, human capital, intellectual capital

\section{JEL Classification G21, G32, J24, M53, M54}

\section{INTRODUCTION}

Assessing a debtor's credit or default risk is a key competence in banking (Lamarque, 2009). It depends - at operational level - on the loan officer (Bruns et al., 2008) who represents the bank's human capital (Andersson, 2004). This human capital, as a component of intellectual capital, has been the focus of numerous contributions to the literature (Kucharcikova, 2014). Many of these contributions describe the two other components of intellectual capital as organizational (or structural) capital and client (or relational) capital, and describe how they interact in particular ways with human capital (Edvinson, 1997). Subsequent research has dealt with the measurement of intellectual capital (Bontis, 1998, 2000; Choudhary, 2010). Linking intellectual capital to business performance or productivity has been achieved in different industries (Bollen et al., 2005; Seleim et al., 2007; Sharabati et al., 2010; Alhassan \& Asare, 2016). Iazolino and Laise (2013) have explored the capacity of intellectual capital to create economic value. Value creation measures based on "VAIC" (Value Added Intellectual Coefficient) have been applied in the banking sector (Saengchan, 2007).

While these different empirical contributions confirm the central role of intellectual capital in the financial performance of banks, a limit- 
ed number of studies question the specific role of human capital in controlling credit risk, particularly since the 2008 financial crisis (Curado, 2008) and the implementation of the Basel II prudential regulations. With this observation as its starting point, this article focuses on the role of human capital in credit risk management, as observed at operational level, and studies the influence of training and experience in the assessment of loan applications (Ottavia et al., 2011). The very nature of credit, as a risky, complex activity, and the regulations that govern it, require a particular type of personnel management (Shih et al., 2010). The literature review conducted by Hardeep and Bakshi (2016) shows that the initial and continuing education, experience and expertise of staff are major features of a bank's human capital (Subramaniam \& Youndt, 2005; Choudhary, 2010).

This contribution starts by reviewing risk management practices in bank and discusses the loan officer's technical and relational approach to risk. Next, we examine the important place of human capital in banking activities, along with its features, before finally assessing the respective influence of training and experience in credit risk assessment and management. Some of our results are counter-intuitive and original: they show that loan officers' ability to anticipate risk depends above all on their training rather than on their experience, and that their degree of experience has little effect on their commitment to client monitoring.

\section{CREDIT RISK MANAGEMENT BY BANKS}

\subsection{Analysis of credit risk}

Credit risk is one of the three main types of risk generated by banking, alongside financial risk and operational risk. It represents the risk that debtors will not respect their commitment to their creditor in terms of debt servicing.

Controlling this risk is the essential competence required in the sector, along with retail banking competences, and is central to the development of competitive advantage (Lamarque, 2009). This control takes the form of an agency relationship, in Jensen and Meckling's (1976) sense, in which the borrower, or "agent", promises the "principal", the bank, to repay the debt, and in which the asymmetric information possessed by each characterizes the relationship. According to Fama (1985), this asymmetry can be counterbalanced by collecting information about the borrower, a crucial activity in banking (Froot \& Stein, 1998). Selecting borrowers in a way that reduces information asymmetry is, according to Freixas and Rochet (2008), the principal role of a bank. Loan officers make this selection by anticipating the default risk when granting credit, and by subsequently monitoring the borrower.

Kharoubi and Thomas (2013) divide credit risk analysis in most cases into "empirical, statisti- cal, and theoretical" assessment, but loan officers mainly conduct empirical analyses when assessing the risk of granting credit. This includes positive approaches (financial analysis and the so-called "tallying" method) and normative approaches (including ratios and ratings). According to Bruns et al. (2008), the mostly used criteria for the "tallying" method, are the " $5 \mathrm{Cs}$ of borrowing". These criteria are: (i) the firm's financial "capacity" to service the debt, (ii) the economic "conditions" in which the loan takes place, (iii) the firm's "capital", (iv) the "collateral" or guarantees provided, and finally (v) the "character" of the borrower, including their education, experience, and integrity (Beaulieu, 1994).

\subsection{Transactional and relational approach to risk}

Through their activity, banks obtain specific, confidential information (Fama, 1985; Nakamura, 1993). The information used by loan officers to assess credit risk can be divided into two types: the first, known as "transactional", comprises objective, quantifiable data, collected from company accounts and presented, for example, in the form of ratios, scores and rating tables; the second type of information is qualitative, and is collected individually by each loan officer. It includes the borrowing firm's business model, competition, technology, management team and stakeholders. It is considered from a long-term, individual perspective. 
The relational approach (Elyasiani \& Goldberg, 2004) is also based on a relationship of trust between the borrower and the loan officer, which helps to reduce the risk. This relationship, explored by Boot (2000) in his literature review, is based on personal contacts between the actors and the consideration of information other than that contained in the accounts or obtained using expert systems. When assessing the solvency of a borrower, the loan officer also considers impressions obtained during discussions with the loan applicant, which provide deeper understanding of the background to the loan and repayment methods (Boot, 2000).

Nonetheless, the loan officers find it more difficult to use information obtained using the relational approach than that obtained from company accounts (Trönnberg \& Hemlin, 2012), and this leads them to take more risky decisions with regard to awarding loans. Degryse and Van Cayseele (2000), like Jiménez and Saurina (2004), confirm that the relational approach generates more risk-taking. However, Berger et al. (2005) observe that the transactional approach is more risky when the use of ratings methods goes beyond its informative role and serves as a basis for the final decision. Ultimately, the use of these approaches, and the weight given to each when anticipating and monitoring credit risk, depends on the loan officer. The approaches lead to differing practices, despite the banks' efforts to standardize procedures. For Andersson (2004), the differences observed in credit risk management within the same bank can be mainly attributed to human capital. This factor explains the variation observed in credit allocation processes by loan officers (Bruns et al., 2008).

\section{HUMAN CAPITAL AND CREDIT RISK MANAGEMENT}

\subsection{Human capital in the banking sector}

There are many macro- and micro-economic approaches to human capital, based on many different theories (Kucharcikova, 2014). At the micro-economic level, human capital is viewed as a key organizational resource. Intellectual capital, including human capital, structural capital, and client or relational capital (Edvinson, 1997), is considered a crucial resource in highly knowledge-intensive activities, while the composition of intellectual capital - beyond these three components - remains the subject of debate and developments in the literature. Mention and Bontis (2013) observe that the banking sector involves a high concentration of intellectual capital, and that its development is extremely important to the management of a bank.

Edvinson's (1997) definition of human capital describes it as a combination of employees' knowledge, experience and skills. In the banking sector, different studies have concluded that human capital has a significant, positive, direct effect on performance (Shih et al., 2010; Mention \& Bontis, 2013). For Shih et al. (2010), the complexity, risky nature and regulation of banking operations demands from managers the systematic, personalized management of staff competencies and experience. Ottavia et al. (2011) describe human capital in the context of credit allocation as "the knowledge, skills and experience used by loan officers to assess and respond to loan applications".

\subsection{The place of training and the role of experience}

The constant growth in the value of human capital observed in the banking sector can be attributed to significant efforts in training, whose economic results fully justify the investments made (Guéry, 2011; Lhomme \& de Massy, 2011). Improvements made in the training organized by banks have improved their level of productivity (Cabrita \& Bontis, 2008). Nonetheless, according to Bruns et al. (2008), the influence of training in the development of human capital in banks depends on its specific features. The "general" component of human capital can be acquired through basic, non-specialist training, providing skills and analytical abilities that apply in most contexts. "Specific" human capital can be developed through specialized training or through experience. It includes competences or "tacit knowledge" that cannot be transferred to a third party or a knowledge system (Berman et al., 2002). For Dimov and Shepherd (2005), the 
loan officers best able to use different approaches to assess credit risk are those represent the highest level of human capital. In view of this, and of our analysis above, we formulate the following hypothesis:

\section{H1: Loan officer training influences credit risk management practices.}

The loan officer's experience also appears to be a key factor in credit allocation decisions (Ottavia et al., 2011). Rodgers' (1999) study of the decision-making process in a sample of loan officers, classified as "experts" and "novices" depending on whether they had more or less than two years' experience, reveals several interesting findings that have been supported by other studies. The experts select the information necessary to process the credit applications with regard to their own mind-map and are better than novices at detecting contradictory information; they reject loan applications when the financial information is limited (Beaulieu, 1994; Rodgers, 1999). Nonetheless, experts find it difficult to assess company default or bankruptcy risk (Andersson, 2004); according to Staw et al. (1997), they are less successful than novices at identifying weak credit applications.

These different contributions lead us to question the influence of loan officer experience on the anticipation and management of credit risk, and to formulate the following hypothesis:

\section{H2: $\quad$ Loan officer experience is a discriminating factor in credit risk management practices.}

\section{METHODOLOGY}

We conducted our field study on loan officers in a major French mutualist bank. We initiated the contact in spring of 2012 and sent a questionnaire to all the loan officers working in business centres and branches in a regional division of the bank, a total of 99 officers. The survey used the "Qualtrics" platform. We obtained a $57 \%$ response rate and analyzed the data in June 2016.

We measured the dependent variable, risk management, on 5-point Likert scale. We tested the two dimensions studied, risk management and risk anticipation, using 4 items developed exclusively for this study and validated during 4 interviews. The 2 independent variables were covered by 2 measures. We measured two types of experience: experience of the bank and experience of the loan officer's work. We measured two types of training: technical training (financial analysis) and regulatory training. We chose the indicators in our questionnaire with regard to our theoretical model and empirical research analyzing human capital, credit risk management in banks and bank-firm relations (Table 1). We tested them during the pre-test interviews.

Because of the structure of the questionnaire, the number of respondents and the types of dependent and independent variables, we used 6 ANOVA analyses to explore the variance of the mean value of risk anticipation and management depending on the level of technical training. We used two correlation analyses to test the links between risk anticipation and management, and the level of regulatory training (Table 2).

Table 1. Measures for the variables used in this study

\begin{tabular}{|c|c|}
\hline Credit risk management & Non-metric: 5 -point Likert scale \\
\hline \multicolumn{2}{|c|}{$\begin{array}{l}\text { Anticipation: } \\
\text { - knowledge of the firm, the company head, its environment de; } \\
\text { - daily processing of "important new irregularities"; } \\
\text { - information collection that can result in a proposal of provisions; } \\
\text { - analysis of latest company accounts, notably when renewing short-term lines } \\
\text { Monitoring: } \\
\text { - by including the risk dimension when setting up the relational program; } \\
\text { - by obtaining support from my expert or branch manager; } \\
\text { - by rigorous monitoring during portfolio reviews and risk committees; } \\
\text { - by monitoring the progress made by the debt recovery and litigation departments on the files they manage }\end{array}$} \\
\hline \multicolumn{2}{|r|}{ Training } \\
\hline Technical training & Non-metric: categorical variable \\
\hline Regulatory training & Non-metric: 5-point Likert scale \\
\hline \multicolumn{2}{|r|}{ Experience } \\
\hline Experience as loan officer & Non-metric: categorical variable \\
\hline Experience at the bank & Non-metric: categorical variable \\
\hline
\end{tabular}


Table 2. Summary of analytical method and techniques

\begin{tabular}{|c|c|c|c|c|}
\hline Hypotheses & Dependent variables & \multicolumn{2}{|c|}{ Independent variables } & Techniques \\
\hline \multirow{2}{*}{$H 1$} & \multirow{4}{*}{ Risk anticipation and management } & \multirow{2}{*}{ Training } & Technical & ANOVA \\
\hline & & & Regulatory & Correlation \\
\hline \multirow{2}{*}{$H 2$} & & \multirow{2}{*}{ Experience } & At the bank & \multirow{2}{*}{ ANOVA } \\
\hline & & & As loan officer & \\
\hline
\end{tabular}

\section{PRESENTATION OF PRINCIPAL RESULTS}

\subsection{The influence of training on credit risk anticipation}

More than $57 \%$ of our respondents have received training giving them access to financial analysis knowledge or including a module in financial analysis (see Table 3). 35\% of them have a Master's degree, and $14 \%$ a Bachelor's degree.

Table 3. Characteristics of the sample studied

\begin{tabular}{|c|c|c|c|}
\hline Characteristics & $\begin{array}{l}\text { Answers } \\
\text { categories }\end{array}$ & Frequency & $\%$ \\
\hline \multirow{3}{*}{$\begin{array}{l}\text { Is loan officer } \\
\text { holding a degree } \\
\text { including a } \\
\text { financial analysis } \\
\text { module or not? }\end{array}$} & No & 24 & 42.11 \\
\hline & Yes & 33 & 57.89 \\
\hline & Total & 57 & 100.00 \\
\hline \multirow{5}{*}{ Type of degree } & Master & 20 & 35.09 \\
\hline & ITB & 1 & 1.75 \\
\hline & Bachelor & 8 & 14.04 \\
\hline & CETCA 2 & 4 & 7.02 \\
\hline & Total & 33 & 57.89 \\
\hline \multirow{3}{*}{$\begin{array}{l}\text { Years' service } \\
\text { in the bank }\end{array}$} & Less than 6 years & 25 & 43.86 \\
\hline & More than 6 years & 32 & 56.14 \\
\hline & Total & 57 & 100.00 \\
\hline \multirow{3}{*}{$\begin{array}{l}\text { Years' service } \\
\text { as loan officer }\end{array}$} & Less than 3 years & 35 & 61.40 \\
\hline & More than 3 years & 22 & 38.60 \\
\hline & Total & 57 & 100.00 \\
\hline \multirow{9}{*}{$\begin{array}{l}\text { Previous position } \\
\text { occupied }\end{array}$} & Customer advisor & 35 & 61.40 \\
\hline & $\begin{array}{c}\text { Administrative } \\
\text { employee }\end{array}$ & 1 & 1.75 \\
\hline & New staff member & 14 & 24.56 \\
\hline & $\begin{array}{l}\text { Commercial } \\
\text { Assistant }\end{array}$ & 1 & 1.80 \\
\hline & Auditor & 1 & 1.80 \\
\hline & $\begin{array}{l}\text { Farmer/Wine- } \\
\text { grower advisor }\end{array}$ & 3 & 3.50 \\
\hline & $\begin{array}{c}\text { Professional client } \\
\text { advisor }\end{array}$ & 1 & 1.80 \\
\hline & $\begin{array}{l}\text { Commercial } \\
\text { assistant }\end{array}$ & 1 & 1.80 \\
\hline & Total & 57 & 100.00 \\
\hline
\end{tabular}

\section{Anticipation and technical training}

Knowledge of the firm and its managing director, and an analysis of its latest financial statements appear necessary to all loan officers, whether or not they are trained in financial analysis (the means of the two groups are almost identical). However, loan officers trained in financial analysis often use information collection to assess risk and for the daily processing of irregular files, whereas loan officers untrained in financial analysis use it rarely if ever (the difference in means is significant at the $5 \%$ level).

Table 4. Results of the ANOVA between technical training and risk anticipation

\section{How do you use risk indicators in your work?}

\begin{tabular}{|c|c|c|c|c|c|}
\hline Items & $\begin{array}{l}\text { Degree } \\
\text { with } \\
\text { financial } \\
\text { analysis } \\
\text { module }\end{array}$ & $\mathbf{N}$ & Mean & $F$ & Sig. \\
\hline \multirow{2}{*}{$\begin{array}{l}\text { Knowledge of } \\
\text { firm, its managing } \\
\text { director, its } \\
\text { environment }\end{array}$} & $\mathrm{No}$ & 24 & 4.17 & \multirow[b]{2}{*}{0.005} & \multirow[b]{2}{*}{0.943} \\
\hline & Yes & 33 & 4.15 & & \\
\hline \multirow{2}{*}{$\begin{array}{l}\text { Daily processing } \\
\text { of "important new } \\
\text { irregularities" }\end{array}$} & No & 24 & 2.96 & \multirow{2}{*}{5.411} & \multirow{2}{*}{$0.024^{* *}$} \\
\hline & Yes & 33 & 3.73 & & \\
\hline \multirow{2}{*}{$\begin{array}{l}\text { Information } \\
\text { collection that can } \\
\text { lead to a proposal } \\
\text { of provisions }\end{array}$} & No & 24 & 2.67 & \multirow[b]{2}{*}{5.497} & \multirow[b]{2}{*}{$0.023^{* *}$} \\
\hline & Yes & 33 & 3.30 & & \\
\hline \multirow{2}{*}{$\begin{array}{l}\text { Analysis of financial } \\
\text { statements, } \\
\text { particularly when } \\
\text { renewing short- } \\
\text { term lines }\end{array}$} & No & 24 & 4.50 & \multirow[b]{2}{*}{0.240} & \multirow[b]{2}{*}{0.626} \\
\hline & Yes & 33 & 4.61 & & \\
\hline
\end{tabular}

Note: ${ }^{* *}$ Significant at $5 \%$.

\section{Anticipation and regulatory training}

The way risk is anticipated can vary depending on the level of regulatory training. The daily processing of new irregular files (correlation coefficient 0.439) and information collection possibly resulting in provisions (coefficient 0.362 ) are characteristic in loan officers with the highest level of regulatory knowledge (respectively significant at the 0.01 level) ${ }^{1}$. Loan

1 Correlations higher than 0.6 are rarely observed for this type of data. In line with previous work, we consider that correlations higher than 0.4 are relatively strong; correlations between 0.2 and 0.4 are moderate, and those lower than 0.2 are weak. 
Table 5. Results of the correlation between regulatory training and anticipation

\begin{tabular}{|c|c|c|c|c|c|c|c|}
\hline \multirow[b]{2}{*}{ Pearson's correlation } & \multicolumn{7}{|c|}{ Regulatory training and anticipation } \\
\hline & \multicolumn{2}{|c|}{$\begin{array}{l}\text { Do you know the duties and } \\
\text { obligations of the banker? }\end{array}$} & \multirow{2}{*}{$\frac{\text { Scale* }^{*}}{\text { Mean }}$} & \multirow[b]{2}{*}{3} & \multirow{2}{*}{$\frac{3}{4.07}$} & \multirow{2}{*}{$\frac{4}{4.23}$} & \multirow{2}{*}{$\begin{array}{l}5 \\
5\end{array}$} \\
\hline \multirow{2}{*}{$\begin{array}{l}\text { Knowledge of firm, its managing } \\
\text { director, its environment }\end{array}$} & Correlation & $\begin{array}{l}0.266^{* *} \\
(0.046)\end{array}$ & & & & & \\
\hline & $N$ & 57 & $N$ & 1 & 28 & 26 & 2 \\
\hline \multirow{2}{*}{$\begin{array}{l}\text { Daily processing of "important new } \\
\text { irregularities" }\end{array}$} & Correlation & $\begin{array}{c}0.439 * * * \\
(0.001)\end{array}$ & Mean & 1 & 3.04 & 3.77 & 5 \\
\hline & $N$ & 57 & N & 1 & 28 & 26 & 2 \\
\hline \multirow{2}{*}{$\begin{array}{l}\text { Information collection that can lead to } \\
\text { a proposal of provisions }\end{array}$} & Correlation & $\begin{array}{c}0.362^{* * *} \\
(0.006)\end{array}$ & Mean & 2 & 2.75 & 3.27 & 4.5 \\
\hline & $N$ & 57 & $\mathrm{~N}$ & 1 & 28 & 26 & 2 \\
\hline \multirow{2}{*}{$\begin{array}{l}\text { Analysis of financial statements, } \\
\text { particularly when renewing short-term } \\
\text { ines }\end{array}$} & Correlation & $\begin{array}{c}0.009 \\
(0.944)\end{array}$ & Mean & 5 & 4.54 & 4.54 & 5 \\
\hline & N & 57 & $\mathrm{~N}$ & 1 & 28 & 26 & 2 \\
\hline
\end{tabular}

Note: ${ }^{\star} 1=$ poorly or not at all, $2=$ poorly, $3=$ moderately, $4=$ well, $5=$ very well, ${ }^{* *}$ significant correlation at the $1 \%$ level; ${ }^{* *}$ significant at the $5 \%$ level.

officers whose level of regulatory training is the highest also analyze the latest financial statements: this result is significant at the $0.05 \%$ level, although the correlation coefficient is relatively weak (0.266).

\subsection{The influence of type of training on credit risk monitoring}

All loan officers know the company and its head, whatever their level of regulatory training.

\section{Monitoring and technical training}

Our analysis of the data collected shows that the type of technical training is a discriminating factor for integration of the risk dimension when setting up a relational program (difference in variances significant at the $5 \%$ level). The same thing can be observed for monitoring files managed by the debt recovery and litigation departments. Loan officers holding a degree with a financial analysis module are more likely to integrate the risk dimension when setting up a relational program to support clients, whereas other loan officers rarely do so. However, whatever their level of technical training, loan officers rarely if ever call on an expert or their branch manager to help with client risk support. All loan officers prefer a method of regularly monitoring files during portfolio reviews and risk committee meetings.

\section{Monitoring and regulatory training}

The results of the correlation analyses show that regulatory training is a discriminatory factor for the inclusion of the risk dimension in relational programs. Loan officers who have received better regulatory training are more likely to include this dimension as a risk management support tool (variance difference significant at the $1 \%$ level). These loan officers

Table 6. Results of the ANOVA between technical training and risk monitoring

\begin{tabular}{|c|c|c|c|c|c|}
\hline \multicolumn{6}{|c|}{ How do you help your clients to manage risk? } \\
\hline Items & $\begin{array}{c}\text { Degree with } \\
\text { financial analysis } \\
\text { module }\end{array}$ & $\mathbf{N}$ & Mean & $\boldsymbol{F}$ & Sig. \\
\hline \multirow{2}{*}{$\begin{array}{l}\text { By including the risk dimension when I set up the relational } \\
\text { program }\end{array}$} & No & 24 & 3.46 & \multirow{2}{*}{4.014} & \multirow{2}{*}{$0.05^{* *}$} \\
\hline & Yes & 33 & 3.91 & & \\
\hline \multirow{2}{*}{ By asking for help from my expert or branch manager } & No & 24 & 2.87 & \multirow{2}{*}{1.820} & \multirow{2}{*}{0.18} \\
\hline & Yes & 33 & 3.18 & & \\
\hline \multirow{2}{*}{$\begin{array}{l}\text { By rigorously monitoring portfolio reviews and risk } \\
\text { committee meetings }\end{array}$} & No & 24 & 4.25 & \multirow{2}{*}{0.157} & \multirow{2}{*}{0.694} \\
\hline & Yes & 33 & 4.33 & & \\
\hline \multirow{2}{*}{$\begin{array}{l}\text { By monitoring the progress of the files managed by the } \\
\text { debt recovery and litigation departments }\end{array}$} & No & 24 & 2.00 & \multirow{2}{*}{4.863} & \multirow{2}{*}{$0.032^{* *}$} \\
\hline & Yes & 33 & 2.64 & & \\
\hline
\end{tabular}

Note: ${ }^{* *}$ Significant at $1 \%$; significant at $5 \%$. 
Table 7. Results of the correlation between technical training and risk monitoring

\begin{tabular}{|c|c|c|c|c|c|c|c|}
\hline \multirow[b]{2}{*}{ Pearson's correlation } & \multicolumn{7}{|c|}{ Regulatory training and support } \\
\hline & \multicolumn{2}{|c|}{$\begin{array}{c}\text { Do you know the duties } \\
\text { and obligations of the } \\
\text { banker? }\end{array}$} & \multirow{2}{*}{$\frac{\text { Scale* }}{\text { Mean }}$} & \multirow{2}{*}{$\frac{1}{1}$} & \multirow{2}{*}{$\begin{array}{c}3 \\
3.61\end{array}$} & \multirow{2}{*}{$\begin{array}{c}4 \\
3.88\end{array}$} & \multirow{2}{*}{$\begin{array}{r}\mathbf{5} \\
4.5\end{array}$} \\
\hline \multirow{2}{*}{$\begin{array}{l}\text { By including the risk dimension when I set up the } \\
\text { relational program }\end{array}$} & Correlation & $\begin{array}{c}0.405^{* * *} \\
(0.002)\end{array}$ & & & & & \\
\hline & $N$ & 57 & N & 1 & 28 & 26 & 2 \\
\hline \multirow{2}{*}{$\begin{array}{l}\text { By asking for help from my expert or branch } \\
\text { manager }\end{array}$} & Correlation & $\begin{array}{c}0.144 \\
(0.286)\end{array}$ & Mean & 3 & 2.93 & 3.15 & 3.5 \\
\hline & $N$ & 57 & $\mathrm{~N}$ & 1 & 28 & 26 & 2 \\
\hline \multirow{2}{*}{$\begin{array}{l}\text { By rigorously monitoring portfolio reviews and } \\
\text { risk committee meetings }\end{array}$} & Correlation & $\begin{array}{l}0.302^{* *} \\
(0.023)\end{array}$ & Mean & 3 & 4.18 & 4.42 & 5 \\
\hline & $N$ & 57 & N & 1 & 28 & 26 & 2 \\
\hline \multirow{2}{*}{$\begin{array}{l}\text { By monitoring the progress of the files managed } \\
\text { by the debt recovery and litigation departments }\end{array}$} & Correlation & $\begin{array}{c}0.432^{* * *} \\
(0.001)\end{array}$ & Mean & 1 & 2.04 & 2.62 & 4.5 \\
\hline & $N$ & 57 & $\mathrm{~N}$ & 1 & 28 & 26 & 2 \\
\hline
\end{tabular}

Note: ${ }^{\star} 1$ = poorly or not at all, $2=$ poorly, $3=$ moderately, $4=$ well, $5=$ very well, ${ }^{* *}$ significant correlation at the 0.01 level; ${ }^{* *}$ significant at the $5 \%$ level.

also rigorously monitor portfolio reviews and risk committee meetings as part of their risk support work (variance difference significant at the $1 \%$ level). Finally, loan officers with better regulatory training also tend to monitor the files managed by the debt recovery and litigation departments (variance difference significant at the $5 \%$ level). Those with less knowledge of regulatory aspects rarely if ever include this dimension in their risk management support. However, whatever their level of regulatory training, loan officers systematically support their clients' risk management with the help of their experts or branch managers (variance difference not significant).

\subsection{The non-discriminatory nature of experience on credit risk anticipation and monitoring}

Of the whole sample, $56 \%$ have worked at the bank's regional division for longer than 6 years, and $61 \%$ worked as a customer advisor, a similar position, before becoming a loan officer.

\section{Anticipation and experience}

Loan officers anticipate default risk in similar ways whatever their level of experience in the banking sector and in their position. Thus, experience is not a determining factor in credit default risk anticipation. Some methods of anticipating are more often used than others, however. Loan officers almost always use their knowledge of the firm, its managing director and its environment, and analyze the latest financial statements, particularly when renewing short-term credit lines. But they use the collection of information for proposing funds and the daily processing of irregular files much less often.

Table 8. Results of the ANOVA between banking experience and risk anticipation

\begin{tabular}{|c|c|c|c|c|c|}
\hline \multicolumn{6}{|c|}{ How do you use risk indicators in your work? } \\
\hline Items & $\begin{array}{l}\text { Seniority at the } \\
\text { bank }\end{array}$ & $\mathbf{N}$ & Mean & $\boldsymbol{F}$ & Sig. \\
\hline \multirow{2}{*}{ Knowledge of firm, its managing director, its environment } & $<6$ years & 25 & 4.28 & \multirow{2}{*}{1.109} & \multirow{2}{*}{0.297} \\
\hline & $>6$ years & 32 & 4.06 & & \\
\hline \multirow{2}{*}{ Daily processing of "important new irregularities" } & $<6$ years & 25 & 3.52 & \multirow{2}{*}{0.365} & \multirow{2}{*}{0.548} \\
\hline & $>6$ years & 32 & 3.31 & & \\
\hline \multirow{2}{*}{$\begin{array}{l}\text { Information collection that can lead to a proposal of } \\
\text { provisions }\end{array}$} & $<6$ years & 25 & 3.16 & \multirow{2}{*}{0.624} & \multirow{2}{*}{0.433} \\
\hline & $>6$ years & 32 & 2.94 & & \\
\hline \multirow{2}{*}{$\begin{array}{l}\text { Analysis of financial statements, particularly when renewing } \\
\text { short-term lines }\end{array}$} & $<6$ years & 25 & 4.56 & \multirow{2}{*}{0.000} & \multirow{2}{*}{0.991} \\
\hline & $>6$ years & 32 & 4.56 & & \\
\hline
\end{tabular}


Table 9. Results of the ANOVA between experience in current position and risk anticipation

\begin{tabular}{|c|c|c|c|c|c|}
\hline \multicolumn{6}{|c|}{ How do you use risk indicators in your work? } \\
\hline Items & $\begin{array}{c}\text { Seniority in your } \\
\text { position }\end{array}$ & $N$ & Mean & $F$ & Sig. \\
\hline \multirow{2}{*}{ Knowledge of firm, its managing director, its environment } & $<3$ years & 35 & 4.09 & \multirow{2}{*}{0.785} & \multirow{2}{*}{0.380} \\
\hline & $>3$ years & 22 & 4.27 & & \\
\hline \multirow{2}{*}{ Daily processing of "important new irregularities" } & $<3$ years & 35 & 3.29 & \multirow{2}{*}{0.765} & \multirow{2}{*}{0.386} \\
\hline & $>3$ years & 22 & 3.59 & & \\
\hline \multirow{2}{*}{$\begin{array}{l}\text { Information collection that can lead to a proposal of } \\
\text { provisions }\end{array}$} & $<3$ years & 35 & 3.00 & \multirow{2}{*}{0.099} & \multirow{2}{*}{0.754} \\
\hline & $>3$ years & 22 & 3.09 & & \\
\hline \multirow{2}{*}{$\begin{array}{l}\text { Analysis of financial statements, particularly when } \\
\text { renewing short-term lines }\end{array}$} & $<3$ years & 35 & 4.51 & \multirow{2}{*}{0.309} & \multirow{2}{*}{0.581} \\
\hline & $>3$ years & 22 & 4.64 & & \\
\hline
\end{tabular}

\section{Monitoring and experience}

Loan officers support their clients in very similar ways, whatever their level of experience. Indeed, experience, both in banking and in the position of loan officer, influence only one kind of support. Rigorous monitoring of client portfolio reviews and risk assessment committees is characteristic of greater seniority both in the banking sector and as a loan officer. The differences in the means are significant at the $5 \%$ level for banking experience and at the $10 \%$ level for experience in the position.
However, whether in the sector or in the position, experience does not make a clear difference to any of the other forms of support. The consideration of risk when implementing a relational program, and the use of a third party, either an expert or the branch manager, are the most common methods used to support risk management, while rigorous monitoring of files during portfolio reviews and risk committee meetings (debt recovery and litigation departments) is secondary, whatever the level of experience in the banking sector or as loan officer.

Table 10. Results of the ANOVA between experience in the bank and risk monitoring

\begin{tabular}{|c|c|c|c|c|c|}
\hline \multicolumn{6}{|c|}{ How do you help your clients to manage risk? } \\
\hline Items & $\begin{array}{l}\text { Seniority at } \\
\text { the bank }\end{array}$ & $\mathbf{N}$ & Mean & $\boldsymbol{F}$ & Sig. \\
\hline \multirow{2}{*}{$\begin{array}{l}\text { By including the risk dimension when I set up the relational } \\
\text { program }\end{array}$} & $<6$ years & 25 & 3.72 & \multirow{2}{*}{0.000} & \multirow{2}{*}{0.990} \\
\hline & $>6$ years & 32 & 3.72 & & \\
\hline \multirow{2}{*}{ By asking for help from my expert or branch manager } & $<6$ years & 25 & 3.12 & \multirow{2}{*}{0.274} & \multirow{2}{*}{0.603} \\
\hline & $>6$ years & 32 & 3.00 & & \\
\hline \multirow{2}{*}{$\begin{array}{l}\text { By rigorously monitoring portfolio reviews and risk committee } \\
\text { meetings }\end{array}$} & $<6$ years & 25 & 4.04 & \multirow{2}{*}{5.276} & \multirow{2}{*}{$0.025^{* *}$} \\
\hline & $>6$ years & 32 & 4.50 & & \\
\hline \multirow{2}{*}{$\begin{array}{l}\text { By monitoring the progress of the files managed by the debt } \\
\text { recovery and litigation departments }\end{array}$} & $<6$ years & 25 & 2.52 & \multirow{2}{*}{0.825} & \multirow{2}{*}{0.368} \\
\hline & $>6$ years & 32 & 2.25 & & \\
\hline
\end{tabular}

Table 11. Results of the ANOVA between experience in the position and risk monitoring

\begin{tabular}{|c|c|c|c|c|c|}
\hline \multicolumn{6}{|c|}{ How do you help your clients to manage risk? } \\
\hline Items & $\begin{array}{l}\text { Seniority in } \\
\text { your position }\end{array}$ & $\mathbf{N}$ & Mean & $\boldsymbol{F}$ & Sig. \\
\hline \multirow{2}{*}{$\begin{array}{l}\text { By including the risk dimension when I set up the relational } \\
\text { program }\end{array}$} & $<3$ years & 35 & 3.60 & \multirow{2}{*}{1.765} & \multirow{2}{*}{0.189} \\
\hline & $>3$ years & 22 & 3.91 & & \\
\hline \multirow{2}{*}{ By asking for help from my expert or branch manager } & $<3$ years & 35 & 3.17 & \multirow{2}{*}{1.779} & \multirow{2}{*}{0.188} \\
\hline & $>3$ years & 22 & 2.86 & & \\
\hline \multirow{2}{*}{$\begin{array}{l}\text { By rigorously monitoring portfolio reviews and risk } \\
\text { committee meetings }\end{array}$} & $<3$ years & 35 & 4.14 & \multirow{2}{*}{3.794} & \multirow{2}{*}{$0.057^{*}$} \\
\hline & $>3$ years & 22 & 4.55 & & \\
\hline \multirow{2}{*}{$\begin{array}{l}\text { By monitoring the progress of the files managed by the debt } \\
\text { recovery and litigation departments }\end{array}$} & $<3$ years & 35 & 2.20 & \multirow{2}{*}{2.121} & \multirow{2}{*}{0.151} \\
\hline & $>3$ years & 22 & 2.64 & & \\
\hline
\end{tabular}




\section{DISCUSSION}

This research reveals several interesting findings. First, it shows that the level of training positively influences credit risk anticipation and monitoring.

The greater the levels of technical or regulatory training, the more loan officers anticipate risk. However, whatever the loan officer's training level, risk anticipation is most often based on knowing the firm, its managing director and its environment. Similarly, all loan officers analyze the latest financial statements when they renew short-term lines. These two dimensions involve general knowledge that does not necessarily require technical or regulatory training. It involves tacit knowledge developed thanks to specialized training (Berman et al., 2002; Gavetti \& Levinthal, 2000).

Our results also show the positive effect of technical and regulatory training on risk monitoring. Indeed, the greater the levels of technical or regulatory training, the more loan officers support their clients by including the risk dimension when they set up a relational program and monitoring changes in the files managed by the debt recovery and litigation departments. Nonetheless, regulatory proves more important than technical training for risk support via rigorous monitoring of portfolio reviews and risk committees. This result confirms the observation of Dimov and Shepherd (2005) that loan officers possessing the highest levels of human capital, measured here by training, are most capa- ble of using different approaches to assess risk. At this level of analysis, we confirm the importance of specific knowledge for credit risk anticipation and management by loan officers. This result aligns with previous research (Forbes, 2005; Ottavia et al., 2011): credit managers with higher education levels than their peers have knowledge that makes them more effective decision-makers.

The results of our research also show that the second component of human capital studied, experience, does not influence anticipation, and only influences a single form of credit risk monitoring. Whatever the nature and degree of their experience, loan officers tend to systematically include every lever in their risk anticipation. This risk may however be affected by the measure used in our questionnaire, at least six years' experience in banking. This long period prevented us from analyzing in detail the influence of this experience on different degrees of credit risk. We therefore analyzed the means by type of response to better interpret the loan officers' responses. The results remained the same; a simple comparison of the means confirms the result of the initial ANOVA, which divided all the responses into two groups of more/less than 6 years' experience. Measured over a shorter period (more/less than 3 years), experience in the position of loan officer does not influence risk anticipation. Whatever their degree of experience in the position, all loan officers systematically use all the different methods of anticipating credit risk.

\section{CONCLUSION}

The banking sector, faced with a context of narrow margins and increased regulatory pressure, has to manage credit risk particularly rigorously, and human capital plays a key role in this. Several studies have shown the importance of human capital in banking, but most of them measure its influence on profitability. Although Ghosh and Maji (2014) highlighted the importance of intellectual capital in the management of bank insolvency risk, our work is, as far as we know, the first to specifically study the role of human capital in managing credit risk. We show that training is more important than experience in default risk anticipation, but that experience is useful in risk monitoring.

These findings have two important implications for credit risk management and human capital. First, both technical and regulatory training is crucial to enable loan officers to anticipate bank credit risk. Second, experience, whether in banking or as a loan officer, only makes a difference in the risk monitoring. These results will be useful when banks are planning recruitment, career management and resource and skills allocation. They also suggest that staff knowledge management will enable banks to use their human capital effectively to reach their own objectives with regard to risk control, and those fixed by the regulators. 
The limitation of our contribution lies in the fact that it studies the role of human capital in controlling credit risk based on only two characteristics: training and experience. This choice, which positions our research outside behavioral dimensions such as loan officers' attitudes, impressions, and intuitions (Hensman \& Sadler-Smith, 2011), has the advantage of a precise research question, but the drawback of taking a technical, impersonal approach to an extremely human process. Further studies could fill this gap. Further research could also study how human capital influences other components of intellectual capital in banks, not only in their value creation process (Mention \& Bontis, 2013), but more specifically in their respective and unique contributions to credit risk anticipation and monitoring.

\section{REFERENCES}

1. Alhassan, A. L., \& Asare, N. (2016). Intellectual capital and bank productivity in emerging markets: evidence from Ghana. Management Decision, 54(3), 589-609. https://doi.org/10.1108/MD-012015-0025

2. Andersson, P. (2004). Does experience matter in lending? A process-tracing study on experienced loan officers' and novices' decision behavior. Journal of Economic Psychology, 25(4), 471-492. https://doi.org/10.1016/S01674870(03)00030-8

3. Beaulieu, P. R. (1994). Commercial lenders use of accounting information in interaction with source credibility. Contemporary Accounting Research, 10(2), 557-585. https://doi. org/10.1111/j.1911-3846.1994. tb00406.x

4. Berger, A. N., Miller, N. H., Petersen, M. A., Rajan, R. G., \& Stein, J. C. (2005). Does function follow organizational form? Evidence from the lending practices of large and small banks. Journal of Financial Economics, 76(2), 237-269. https://doi.org/10.1016/j. jfineco.2004.06.003

5. Berman, S. L., Down, J., \& Hill, C. W. L. (2002). Tacit knowledge as a source of competitive advantage in the National Basketball Association. Academy of Management Journal, 45(1), 13-31. Retrieved from https://journals.aom. org/doi/abs/10.5465/3069282

6. Bollen, L., Vergauwen, P., \& Schnieders, S. (2005). Linking intellectual capital and intellectual property to company performance. Management Decision,
43(9), 1161-1185. https://doi. org/10.1108/00251740510626254

7. Bontis, N. (1998). Intellectual capital: an exploratory study that develops measures and models. Management Decision, 36(2), 63-76. https://doi. org/10.1108/00251749810204142

8. Bontis, N. (2000). Assessing knowledge assets: A review of the models used to measure intellectual capital. International Journal of Management Review, 3(1), 4160. https://doi.org/10.1111/14682370.00053

9. Boot, A. W. A. (2000). Relationship Banking: what do we know? Journal of Financial Intermediation, 9(1), 7-25. https://doi.org/10.1006/ jfin. 2000.0282

10. Bruns, V., Holland, D. V., Shepard, D. A., \& Wiklund, J. (2008). The role of human capital in loan officers' decision policies. Entrepreneurship, Theory and Practice, 32(3), 485-506. http://doi.org/10.1111/j.15406520.2008.00237.x

11. Cabrita, M., \& Bontis, N. (2008). Intellectual capital and business performance in the Portuguese banking industry. International Journal of Technology Management, 43(1-3), 1-26. https://doi. org/10.1504/IJTM.2008.019416

12. Choudhary, J. (2010). Performance impact of intellectual capital: A study of Indian IT sector. International Journal of Business and Management, 5(9), 72-80. https:// doi.org/10.5539/ijbm.v5n9p72.

13. Curado, C. (2008). Perceptions of Knowledge Management and Intellectual Capital in The Banking Industry. Journal of Knowledge Management, 12(3), 141-155. https://doi. org/10.1108/13673270810875921

14. Degryse, H., \& Van Cayseele, P. (2000). Relationship lending within a bank-based system: evidence from European small business data. Journal of Financial Intermediation, 9(1), 90-109. https://doi. org/10.1006/jin. 1999.0278

15. Dimov, D. P., \& Shepherd, D. A. (2005). Human capital theory and venture capital firms: Exploring "home runs" and "strike outs". Journal of Business Venturing, 20(1), 1-21. http://dx.doi.org/10.1016/j. jbusvent.2003.12.007

16. Edvinson, L. (1997). Developing intellectual capital at Skandia. Long Range Planning, 30(3), 366-373. https://doi.org/10.1016/ S0024-6301(97)90248-X

17. Elyasiani, E., \& Goldberg, L. G. (2004). Relationship lending: a survey of the literature. Journal of Economics and Business, 56(4), 315-330. https://doi.org/10.1016/j. jeconbus.2004.03.003

18. Fama, E. F. (1985). What's Different About Banks? Journal of Monetary Economics, 15(1), 29-39. https://dx.doi.org/10.1016/03043932(85)90051-0

19. Forbes, D. P. (2005). Managerial determinants of decision speed in new ventures. Strategic Management Journal, 26(4), 355-366. https://doi.org/10.1002/smj.451

20. Freixas, X., \& Rochet, J. C. (2008) Microeconomics of banking. Cambridge: MIT ed.

21. Froot, K., \& Stein, J. (1998). Risk management, capital budget- 
ing, and capital structure policy for financial institutions: An integrated approach. Journal of Financial Economics, 47(1), 55-82. https://doi.org/10.1016/S0304405X(97)00037-8

22. Gavetti, G., \& Levinthal, D. (2000). Looking forward and looking backward: Cognitive and experiential search. Administrative Science Quarterly, 45(1), 113-137. https://doi. org/10.2307\%2F2666981

23. Ghosh, S. K., \& Maji, S. G. (2014). The impact of intellectual capital on bank risk: Evidence from Indian banking sector. IUP Journal of Financial Risk Management, 11(3), 18-38. Retrieved from https://ssrn. com/abstract $=2633458$

24. Guéry, J. C. (2011). Valorisation du capital humain dans la banque. Revue d'économie financière, 4(104), 195-208. https://doi. org/10.3917/ecofi.104.0195

25. Hardeep, H., \& Bakshi, P. (2016). Measurement of Intellectual Capital in the Indian Banking Sector. Vikalpa: the Journal for Decision Makers, 41(1), 61-73. Retrieved from http:// journals.sagepub.com/doi/ full/10.1177/0256090916629253

26. Hensman, A., \& Sadler-Smith, E. (2011). Intuitive decision making in banking and finance. European Management Journal, 29(1), 5166. http://dx.doi.org/10.1016/j. emj.2010.08.006

27. Iazzolino, G., \& Laise, D. (2013). Value added intellectual coefficient (VAIC): A methodological and critical review. Journal of Intellectual Capital, 14(4), 547-563. https://doi.org/10.1108/JIC-122012-0107

28. Jensen, M. C., \& Meckling, W. H. (1976). Theory of the firm: managerial behavior, agency costs, and ownership structure. Journal of Financial Economics, 3(4), 305360. https://doi.org/10.1016/0304405X(76)90026-X

29. Jimenez, G., \& Saurina, J. (2004). Collateral, type of lender and relationship banking as determinants of credit risk. Journal of Banking \& Finance, 28(9), 2191-2212. https://doi.org/10.1016/j.jbankfin.2003.09.002

30. Kharoubi, C., \& Thomas, P. (2013). Analyse du risque de crédit: Banque et Marchés. Paris: Revue Banque Édition.

31. Kucharcíkova, A. (2014). Investment in the Human Capital as the Source of Economic Growth. Periodica Polytechnica, Social and Management Sciences, 22(1), 29-35. https://doi.org/10.3311/PPso.7426

32. Lamarque, E. (2009). La banque sait-elle encore gérer le risque? Revue française de gestion, 8-9(198-199), 193-207. Retrieved from https://www.cairn.info/ revue-francaise-de-gestion2009-8-page-193.htm

33. Lhomme, G., \& Robert de Massy, O. (2011). La formation: un investissement nécessaire pour le capital humain des banques. Revue d'économie financière, 4(104), 179-194. https://doi. org/10.3917/ecofi.104.0179

34. Mention, A. L., \& Bontis, N. (2013). Intellectual capital and performance within the banking sector of Luxembourg and Belgium. Journal of Intellectual Capital, 14(2), 286-309. https://dx.doi. org/10.1108/14691931311323896

35. Nakamura, L. I. (1993). Recent Research in Commercial Banking: Information and Lending. Financial Markets, Institutions \& Instruments, 2(5), 73-88.

36. Ottavia, Chuluunbaatar, E., Kung, S. F., \& Luh, D. B. (2011). SME loan decision making process; the declining role of human capital. Asian Academy of Management Journal, 16(2), 29-52. Retrieved from http://web.usm.my/ aamj/16.2.2011/AAMJ_16.2.2.pdf

37. Rodgers, W. (1999). The influence of conflicting information on novices and loan officers actions. Journal of Economic Psychology, 20(20), 123-145. https://doi.org/10.1016/ S0167-4870(99)00002-1

38. Saengchan, S. (2007). The role of intellectual capital in creating value in banking industry. Journal of Knowledge Management, 3(2), 15-25. Retrieved from https:// www.researchgate.net/publica-
tion/238503938_The_Role_of_Intellectual_Capital_in_Creating_ Value_in_the_Banking_Industry

39. Seleim, A., Ashour, A., \& Bontis, N. (2007). Human capital and organizational performance: a study of Egyptian software companies. Management Decision, 45(4), 789-901. https://doi. org/10.1108/00251740710746033

40. Sharabati, A., Jawad, S., \& Bontis, N. (2010). Intellectual capital and business performance in the pharmaceutical sector of Jordan. Management Decision, 48(1), 105-131. https://doi. org/10.1108/00251741011014481

41. Shih, K. H., Chang, C. J., \& Lin, B. (2010). Assessing knowledge creation and intellectual capital in banking industry. Journal of Intellectual Capital, 11(1), 74-89. https://doi. org/10.1108/14691931011013343

42. Staw, B. M., Koput, K. W., \& Barsade, S. G. (1997). Escalation at the credit window: longitudinal study of bank executives' recognition and write-off of problem loans. Journal of Applied Psychology, 82(1), 130-142. https://doi. org/10.1037/0021-9010.82.1.130

43. Subramaniam, M., \& Youndt, M. (2005). The influence of intellectual capital on the types of innovative capabilities. Academy of Management Journal, 48(3), 450-463. https://doi.org/10.5465/ amj.2005.17407911

44. Trönnberg, C.-C., \& Hemlin, S. (2014). Lending decision making in banks: A critical incident study of loan officers. European Management Journal, 32(2), 362372. https://doi.org/10.1016/j. emj.2013.03.003 